\title{
ОЦЕНКА СИСТЕМЫ ПОКАЗАТЕЛЕЙ ДЕЯТЕЛЬНОСТИ МНОГОПРОФИЛЬНЫХ УНИВЕРСИТЕТОВ
}

\section{(c) 2019 Янова Елена Алексеевна}

кандидат экономических наук, доцент факультета технологического менеджмента и инноваций

Санкт-Петербургский национальный исследовательский университет информационных технологий, механики и оптики (Университет ИТМО), Россия, Санкт-Петербург

E-mail: yanova.ea@gmail.com

\section{(C) 2019 Валдайцева Мария Викторовна}

старший преподаватель факультета технологического менеджмента и инноваций

Санкт-Петербургский национальный исследовательский университет информационных технологий, механики и оптики (Университет ИТМО), Россия, Санкт-Петербург

E-mail: jelma93@yandex.ru

В статье проанализированы основные показатели деятельности многопрофильных университетов Северо-Западного федерального округа, дана оценка основных показателей деятельности, отражена авторская позиция о необходимости совершенствования системы показателей мониторинга эффективности, сделана попытка определить реальное «пороговое значение» мониторинга эффективности для данной группы университетов.

Ключевые слова: многопрофильные вузы, показатели мониторинга эффективности, оценка результатов деятельности, анализ, рейтинг.

В настоящее время, как никогда, возрастает роль и значение высшего образования - подготовки квалифицированных специалистов, являющихся главным фактором развития экономики. В связи с этим возрастает роль инновационной деятельности многопрофильных университетов, предполагающая новые требования к выбору наиболее эффективных показателей мониторинга и оценки результатов их деятельности. Потому назрела необходимость, постоянного, совершенствования системы индикаторов и их критериев, которые отражают результативность деятельности ВУЗов, ориентирующуюся на ключевые отрасли реального сектора экономики.

Несовершенство критериев мониторинга эффективности учебных заведений российские давно отмечено учеными-экономистам $[1,2,4]$. Это связано с тем, что сегодня глобальная конкуренция захватывает не только национальную и региональную реальную экономики, но все больше проникает в сферу высшего образования [9]. Также не следует забывать о структурных изменениях в современной инновационной экономике России, являющихся одними из основных факторов экономического роста реальной экономики [10].

В соответствии с действующим законодательством о высшем образовании, в России

проходит реформирование образовательных организаций высшего образования, основной целью которых является достижение более высоких показателей эффективной деятельности ВУЗов, как на национальном уровне, так и на мировом. С одной стороны, ведущие российские университеты достигли высоких показателей на национальном образовательном рынке, а с другой стороны - возникает необходимость их дальнейшего развития и вхождения в международное образовательное пространство.

В декабре 2012 года принят Федеральный закон «Об образовании в Российской Федерации», где дано определение понятия «мониторинга в системе образования» [6].

Исследованием проблемы мониторинга эффективности российских ВУЗов занято множество ученых-экономистов и практиков: Винокуров М.А., Ильинский М.И., Мотова Г.Н., Прохоров С.Г., Янова В.В., Янова Е.А. и другие. Обобщив мнение которых, можно прийти к выводу, что мониторинг ВУЗа - это система сбора количественной и фактической информации по основным направлениям деятельности ВУЗа: образовательной, научно-исследовательской, международной и другие [2, 4].

Некоторые авторы предполагают, что мониторинг эффективности ВУЗов - это инструмент, 
позволяющий «избавиться от нежелательных элементов» на рынке высшего образования или же механизм определения точек роста, развитие которых позволит повысить качество отечественного образования [5].

По нашему мнению, мониторинг эффективности университета - это процесс сбора, обработки информации, а также проведение комплексного многофакторного анализа состояния и перспектив развития ВУЗа. При его проведении важно учитывать три основных момента:

- непрерывность (сбор, обработка, анализ и оценка данных должна проводиться постоянно);

- диагностичность (наличие моделей или критериев, с помощью которых можно соотнести реальное состояние объекта, системы или процесса);

- научность (способствует применению обоснованных моделей и отслеживанию параметров в процессы любого производства) и др.

Исследования данной проблематики проводилось по целевым показателям эффективности деятельности образовательных организаций высшего образования на основе общепринятой Методики Министерства образования и науки РФ [3]. Несмотря на то, что Методика расчета показателей мониторинга эффективности ВУЗов постоянно совершенствуется, считаем необходимо ее адаптировать с учетом региональной и отраслевой специфик, а также организационно-правовых форм хозяйствования.

Основными показателями деятельности любого ВУЗа являются показатели мониторинга эффективности образовательных организаций (учреждений) высшего образования. Авторами отобраны лучшие многопрофильные университеты г. Санкт-Петербург - ведущие в области математических и естественны наук; инженерного дела; технологических и технических наук; наук об обществе,- с различными организационно-правовыми формами хозяйствования: федеральные государственные бюджетные образовательные учреждения высшего образования (ФГБОУ ВО) и федеральные государственные автономные образовательные учреждения высшего образования (ФГАОУ ВО).

В России впервые мониторинг эффективности вузов проводился в 2012 году по пяти ключевым показателям деятельности образовательного учреждения (организации) высшего образования. В тот период времени ВУЗы были разделены на две группы: эффективные и неэф- фективные вузы (последние - при выполнении двух и более показателей из пяти возможных). Предусматривалось только условное распределение учебных заведений на указанных две укрупненных группы, а без более мелкой градации с точки зрения эффективности. Подобный подход, по нашему мнению, не отражал полноту и сегментацию конкурентной среды высшего образования России.

С тех пор прошло семь лет и в Методике проведения мониторинга произошли существенные изменения как в наборе самих показателей, а также критериев и их пороговых значений. Проанализируем критерии пороговых значений мониторинга вузов России за последние семь лет (табл.1) [3].

Показатель «Образовательная деятельность», оценивался в рамках среднего балла ЕГЭ (в расчете на один предмет), пороговое значение которого в 2012 году составило 60,00 баллов, в 2018 году - значение показателя достигло 66,38 балла, т.е. данный индикатор увеличился на 10,6\%.

Показатель «Научно-исследовательская деятельность» (НИД) - пороговое значение объем НИОКР в расчете на одного научно-педагогического работника (НПР) (тыс.руб. в год) увеличилось почти в 2,5 раза. По НИД считаем необходимо ввести дополнительный показатель - Российский индекс научного цитирования (РИНЦ), который более точно характеризует научно-исследовательскую деятельность вуза, так как этот показатель во всем мире определяет ценность научной школы образовательной организации (учреждения) высшего образования.

Многие российские ученые считают, что следует учитывать РИНЦ при оценке научно-исследовательской деятельности ВУЗа, так как он является универсальным показателем для всех вузов любой специальности, в то время как Web of Science и SCOPUS отражают востребованность научной продукции, главным образом, в области естественных и технических наук [1].

Показатель «Международная деятельность» оценивался как доля иностранных студентов в общей численности студентов по приведенному контингенту. За анализируемый период времени особенно быстрыми темпами увеличилось пороговое значение данного показателя - почти в пять раз. Однако в мировых рейтингах образовательных организаций этот показатель находится в числе ключевых - доля студентов-иностранцев должна составлять не менее 
Таблица 1. Показатели мониторинга эффективности вузов России

\begin{tabular}{|c|c|c|c|c|c|}
\hline \multirow{2}{*}{$\begin{array}{l}\text { № } \\
\Pi / \Pi\end{array}$} & \multirow{2}{*}{ Показатели мониторинга } & \multicolumn{3}{|c|}{ Пороговое значение, годы } & \multirow{2}{*}{$\begin{array}{r}2018 \text { г. к } \\
2012 \text { г., \% }\end{array}$} \\
\hline & & 2012 г. & 2016 г. & 2017-2018 гг. & \\
\hline 1. & $\begin{array}{l}\text { Образовательная деятельность, средний } \\
\text { балл ЕГЭ }\end{array}$ & 60,00 & 66,38 & 66,38 & 110,6 \\
\hline 2. & $\begin{array}{l}\text { Научно-исследовательская деятельность, } \\
\text { объем НИОКР в расчете на одного НПР в } \\
\text { год, тыс.руб. }\end{array}$ & 50,0 & 122,41 & 122,41 & 244,8 \\
\hline 3. & $\begin{array}{l}\text { Международная деятельность, удельный вес } \\
\text { численности иностранных студентов,\% }\end{array}$ & 1,0 & 4,92 & 4,92 & 492,0 \\
\hline 4. & $\begin{array}{l}\text { Финансово-экономическая деятельность, } \\
\text { доход по всем видам деятельности, в расче- } \\
\text { те на одного НПР в год, тыс.руб. }\end{array}$ & 1100,00 & 1839,87 & 1839,87 & 167,3 \\
\hline 5. & $\begin{array}{l}\text { Заработная плата ППС, к средней зарплате } \\
\text { по экономике региона,\% }\end{array}$ & - & 133,0 & 150,0 & 112,8 \\
\hline 6. & $\begin{array}{l}\text { Трудоустройство, удельный вес выпускни- } \\
\text { ков трудоустроивших,\% }\end{array}$ & - & 75,0 & 70,0 & 93,3 \\
\hline 7. & Дополнительный показатель & - & 4,52 & 4,52 & 100,0 \\
\hline 8 & $\begin{array}{l}\text { Инфраструктура: общая площадь учебно-ла- } \\
\text { бораторных помещений на одного приве- } \\
\text { денного студента, кв. метров }\end{array}$ & 11,0 & - & - & - \\
\hline
\end{tabular}

Источник. Составлено авторами на основе данных: http://indicators.miccedu.ru/monitoring/

10\% от общей численности студентов.

Показатель «Финансово-экономическая деятельность» - определяется доходом по всем видам деятельности, в расчете на одного НПР (тыс. руб. в год). Так в 2012 году составлял 1100,00 тыс. руб., тогда как в 2016 году - значение показателя возросло до уровня 1839,87 тыс.руб., то есть увеличилась в 1,7 раза. В последующие годы (2017 и 2018 гг.) он остался на прежнем уровне.

Кроме того, в течение анализируемого периода (2012-2018 гг.) перечень индикаторов пополнился новыми показателями мониторинга эффективности ВУЗов и менялись их критерии:

- показатель «Заработная плата ППС» - в расчете к средней заработной платы по экономике региона,\%;

- показатель «Трудоустройство» - удельный вес выпускников трудоустроившихся,\%;

- показатель «Дополнительный показатель», для вузов, имеющих специфику, был введен дополнительный критерий эффективности.

В результате проведенного анализа показателей мониторинга за последние семь лет выявлены значительные изменения (увеличение) в пороговых значениях индикаторов. Это, прежде всего, по мнению авторов должно быть связано с вопросом постоянного совершенствования самой системы показателей, его критериев, которые должны коррелировать с показателями, применяемыми в рамках процедуры государственной аккредитации ВУЗа.
В настоящее время по итогам мониторинга эффективности ВУЗов принимаются управленческие решения, подчас очень жесткие (закрытие вуза, реорганизация, дополнительные проверки и т.д.). Однако в «реальной жизни» университет, прошедший государственную аккредитацию и имеющий современную собственную материально-техническую базу, ведущий эффективно финансово-хозяйственную деятельность, оказывается в группе неэффективных ВУЗов. Это порождает феномен, известный в теории управления как поведение, ориентированное на «контроль», результатом которого является «перестраховка», попытка «подправить» показатели (в том числе посредством сокращения численности НПР, предусматривающее возможность «улучшения» почти всех индикаторов мониторинга) [5, 11].

В начале 2016 года RAEX (Эксперт PA) стало первой в России и четвертой в мире организацией, рейтинги ВУЗов которой успешно прошли международный аудит IREG Observatory.

Рейтинг (английское слово «rate» - оценивать) - это числовой или порядковый показатель, который демонстрирует значимость или важность объекта исследования. В основе любого рейтинга лежит оценка, которая основывается на конкретном критерии или на определенной системе расчета показателей. Главной задачей рейтингов является оценка объектов, составляемые независимыми рейтинговыми 
агентствами [8].

Рейтинг образовательной организации высшего образования формируется на основе показателей и критериев мониторинга эффективности ВУЗов в целом, а также по отдельным реализуемым образовательным программам; характеризует его значимость и оценку значимости, масштабности, важности объекта на рынке образовательных услуг, место, позицию образовательной организации по сравнению с другими участниками на основе совокупности критериев и индикаторов. Далее представлены результаты аналитической работы по изучению показателей рейтинга RAEX ВУЗов Северо-Западного федерального округа Российской Федерации (СЗФО РФ) и сравнению в показателями мониторинга эффективности.

СЗФО РФ образован 13 мая 2000 г. с населением около 14 млн. жителей (по состоянию на 01.01.2017 г.), что составляет 9,5\% населения России. В его состав входит 11 субъектов Российской Федерации; административным центром является г. Санкт-Петербург с численностью населения около 5300 тыс. человек.

Университеты данного федерального округа в течение последних четырех лет активно и довольно успешно «входят» в рейтинги 100 лучших ВУЗов России и зарубежные рейтинги, «оказы- вая» активную положительную динамику. Проанализируем показатели RAEX университетов СЗФО РФ, входящие в рейтинги 100 лучших вузов России (табл.2).

Согласно данным рейтинга 100 лучших вузов России агентства Эксперт РА 14 университетов СЗФО РФ (14,0\% от общей численности ВУЗов России) вошли в него, что отражает высокие показатели высшего образования федерального округа, в том числе 11 университетов (78,6\% от численности вузов СЗФО РФ) расположены г. Санкт-Петербург - одном из научно-образовательных «столиц» нашего государства.

СПбГУ, имеющий статус уникального научно-образовательного комплекса, старейшего ВУЗа страны, имеющего важнейшего значения для развития российского общества, за последние четыре года (2015-2018 гг.) динамично развивается, что находит отражение в динамике его рейтинговой позиции. Так, например, в российском рейтинге 100 лучших ВУЗов России в 2016 году СПбГУ «поднялся» с 6-го места до 5-го; по уровню качества образования - занимает одно из ведущих мест в стране (5-е место); по востребованности выпускников (12-е место) и уровню научно-исследовательской деятельности (6-е место). В 2017 году данный университет значительно улучшил свои показатели и «поднялся» с

Таблица 2. Рейтинги 100 лучших вузов России университеты СЗФО РФ

\begin{tabular}{|c|c|c|c|c|c|c|c|}
\hline \multirow[b]{2}{*}{ Название вузов } & \multicolumn{4}{|c|}{$\begin{array}{c}\text { Занимаемое место вуза в } \\
\text { рейтинге, годы }\end{array}$} & \multicolumn{3}{|c|}{ Уровень ранга (2017 г. / 2018 г.) } \\
\hline & 2018 & 2017 & 2016 & 2015 & $\begin{array}{c}\text { качество } \\
\text { образования }\end{array}$ & \begin{tabular}{|c|} 
востребо- \\
ванность \\
выпускников
\end{tabular} & $\begin{array}{c}\text { научно-ис- } \\
\text { следователь- } \\
\text { ская дея- } \\
\text { тельность }\end{array}$ \\
\hline СПбГУ (ведущий) & 4 & 4 & 5 & 6 & $4 / 4$ & $12 / 10$ & $5 / 5$ \\
\hline СПб ПУ & 10 & 10 & 11 & 11 & $12 / 12$ & $13 / 14$ & $8 / 7$ \\
\hline Университет ИТМО & 15 & 19 & 19 & 22 & $15 / 13$ & $47 / 35$ & $12 / 8$ \\
\hline ПСПбГМУ & 24 & 22 & 23 & 25 & $18 / 22$ & $25 / 24$ & $33 / 35$ \\
\hline СПбГЭУ & 33 & 33 & 29 & 34 & $27 / 28$ & $56 / 38$ & $82 / 69$ \\
\hline СПб Горный университет & 44 & 36 & 33 & - & $31 / 38$ & $46 / 65$ & $62 / 64$ \\
\hline СПб ЭТУ «ЛЭТИ» & 39 & 41 & 36 & 26 & $36 / 36$ & $80 / 72$ & $44 / 39$ \\
\hline РГПУ им. Герцена & 42 & 40 & 40 & 42 & $38 / 39$ & $73 / 73$ & $36 / 52$ \\
\hline СЗГМУ & 47 & 44 & 46 & 46 & $44 / 49$ & $37 / 28$ & $95 / 105$ \\
\hline СПбГАСУ & 59 & 63 & 64 & 70 & $85 / 76$ & $40 / 34$ & $77 / 75$ \\
\hline Петрозаводский ГУ & 82 & 83 & - & - & $84 / 82$ & $90 / 98$ & $71 / 71$ \\
\hline Северный (Арктический) ФУ & 83 & 87 & - & 94 & $53 / 52$ & $114 / 122$ & $116 / 119$ \\
\hline БФУ им. И. Канта & 90 & 94 & 99 & 85 & $79 / 70$ & $107 / 114$ & $94 / 90$ \\
\hline СПб ГТИ(ТУ) & - & 100 & 90 & 93 & 112/- & $85 /-$ & $74 /-$ \\
\hline
\end{tabular}

Источник. Составлено авторами на основе данных: https://raexpert.ru/ 
5-го места на 4-е; по уровню качества образования - занимает одно из ведущих мест в стране (4-е место); по уровню научно-исследовательской деятельности 5-е место, также имеет одни из наилучших позиций и по востребованности выпускников. В 2018 году стабильно удерживал 4-е место по всем показателям, а по востребованности выпускников поднялся еще на два пункта.

Из пятнадцати первых участников программы повышения международной конкурентоспособности («Проект 5-100») наилучшую положительную динамику продемонстрировал Университет ИТМО, который в 2016 году впервые вошел в «ТОП-20» рейтинга RAEX, поднявшись с 22-го на 19-е место. В 2017 году сохранил 19-е место в рейтинге 100 лучших ВУЗов России. В 2018 году данный университет в результате динамичного развития значительно улучшил свои показатели и «поднялся» на 15-е место в целом, а также повысил свои показатели по качеству образования, востребованности выпускников и научно-исследовательской деятельности.

Другой участник программы «Проект 5-100»- СПб ПУ, в течения ряда лет обладает стабильными позициями на рынке образовательных услуг и занимает 11-е место среди 100 лучших ВУЗов России в 2016 году, по востребованности выпускников - 10-е место, а по научно-исследовательской деятельности - 8-е место. Однако в рейтинге RAEX 2017 году впервые поднялся на 10-е место,, которое сохранил в 2018 году, но и сумел повысить показатели по научно-исследовательской деятельности.

Вузы СЗФО РФ в 2018 году также «приняли участие» в мониторинге эффективности: всего 134 образовательные организации высшего образования, в т.ч. 89 государственных и муниципальных ВУЗов и 45 частных ВУЗов. В целом - в федеральном округе успешно функционируют 2 федеральных университета, 4 национальных исследовательских университета, 4 участника программы «Проект 5-100» и 46 филиалов ВУЗов. Всего в ВУЗах СЗФО РФ обучаются 425464 студентов, что составляет 9,97\% от общего контингента студентов ВУЗов РФ. В основном - это студенты государственных и муниципальных ВУЗов - 92,6\%; и лишь 7,4\% являются студентами частных ВУЗов.

На основе интегрированного показателя уровня конкурентоспособности г. Санкт-Петербург занимает наивысшее место в СЗФО РФ, име- ет статус города федерального значения и имеет широко развитую систему высшего образования. ВУЗы г. Санкт-Петербург с 2012 года постоянно участвуют в мониторинге эффективности образовательных организаций высшего образования. Например, в 2018 году участвовали 71 учебное заведение высшего образования, в том числе 43 государственных и муниципальных ВУЗа и 28 частных. Кроме того, в городе функционирует 6 филиалов организаций высшего образования, 4 национальных исследовательских университета, 3 университета - участники «Проекта 5-100». В г. Санкт-Петербург получают высшее образование 298148 студентов бакалавриата, специалитета, магистратуры, что составляет около 7\% контингента в РФ, в том числе 211286 - студенты очной формы обучения, из которых 151413 студентов получают образование за счет бюджетных средств. В основном студенты обучаются в государственных и муниципальных ВУЗах, что составляет $92,4 \%$ и лишь $7,6 \%$ - в частных вузах.

В рамках данного исследования авторами выбраны лучшие многопрофильные университеты региона, различных организационно-правовых форм хозяйствования (ФГБОУ ВО и ФГАОУ ВО). С целью проведения сравнительного анализа мониторинга эффективности деятельности университеты были сгруппированные по организационно-правовым формам хозяйствования.

Первая группа, федеральное государственное бюджетное образовательное учреждение высшего образования (ФГБОУ ВО): СПбГУ, СПб ГЭУ, СПб Горный университет, СПб ГТИ (ТУ). В первую группу вошли многопрофильные вузы, которые участвовали в рейтингах 100 лучших вузов России, ежегодно проходили мониторинги эффективности деятельности и были включены в группу эффективных вузов. Однако полученные критерии показателей мониторинга данных университетов разнообразны.

Вторая группа, федеральное государственное автономное образовательное учреждение высшего образования (ФГАОУ ВО): СПб ПУ, Университет ИТМО, СПб ЭТУ «ЛЭТИ». В данную группу вошли университеты - участники рейтингов 100 лучших ВУЗов России, которые ежегодно проходят процедуру мониторинга эффективности. Кроме того данные вузы являются участниками программы «Проект 5-100»- автономные образовательные организации высшего образования, более независимые, самостоятельные в 
своих управленческих решениях во всех видах деятельности.

Проанализируем контингент студентов и НПР многопрофильных университетов г. Санкт-Петербург (табл.3). По численности студентов в Санкт-Петербурге среди анализируемых ВУЗов самым крупным является Санкт-Петербургский политехнический университет Петра Великого (СПб ПУ), где обучается 29095 студентов, в т.ч. иностранных - 3706. Второе место (по численности студентов) занимает СПбГУ, где получает образование 18832 студента, в т.ч. иностранных - 1939; третье - СПб ГЭУ13074 студента, в т.ч. иностранных - 947. Однако по показателю численности иностранных студентов - третье место занимает Университет ИТМО - 1663 обучающихся.

Доля студентов среди анализируемых ВУЗов первой группы (ФГБОУ ВО), обучающихся за счет бюджетных средств, колеблется от 37,9\% (в СПб ГТИ (ТУ)) до 92,8\% (в СПб Горный университет); в вузах второй группы - доля студентов обучающихся за счет бюджетных средств, колеблется от 51,9\% (в СПб ПУ) до 80,7\% (в СПб ЭТУ «ЛЭТИ»).

По показателю общей численности работников ВУЗов 1-е место занимает СПбГУ - 9856 чел., в том числе НПР составляет - 3871 чел., из них 77,3\% - имеют ученые степени и звания. 2-е место - занимает СПб ПУ - 4723 чел., в том числе НПР составляет - 1658 чел., из них имеют уче- ные степени и звания 74,7\%. 3-е место «принадлежит» Университету ИТМО - 3001 чел., в том числе НПР составляет - 803 чел., из них 71,2\% обладают учеными степенями и званиями.

Согласно ФГОС ВО, университеты, которые ведут образовательные программы магистратуры, аспирантуры, докторантуры, доля НПР, имеющих ученые степени и звания должна быть не менее 80\%. Однако только три университета в 2018 году соответствуют требованиям федеральных стандартов - СПБ ГЭУ $(82,5 \%)$, СПб ГТИ (ТУ) (80,6\%) и СПб Горный университет $(92,1 \%)$. Кроме того, среди анализируемых университетов второй группы (ФГАОУ ВО) сформировалось неравномерное соотношение НПР к общей численности работников, которое колеблется в пределах от 26,8\% до 42,7\% - при среднем показателе по г. Санкт-Петербург - 41,5\%.

В 2018 году многопрофильные университеты вели образовательную деятельность семи укрупненных сфер научных интересов, в рамках которых отмечено также неравномерное распределение долей обучающихся студентов между ними. На основе результатов проведенного исследования четырех основных сфер наибольшую долю имеют:

- в математических и естественных науках - СПбГУ (42\%), СПб ПУ $(14,4 \%)$ и Университет ИТМО (7,4\%) в России;

- в инженерном деле, технологических и

Таблица 3. Контингент студентов и НПР многопрофильных университетов г. Санкт-Петербург в 2018 году

\begin{tabular}{|c|c|c|c|c|c|c|c|}
\hline \multirow[b]{2}{*}{$\begin{array}{c}\text { Наименование } \\
\text { показателя }\end{array}$} & \multicolumn{4}{|c|}{ Первая группа - ФГБоУ Во } & \multicolumn{3}{|c|}{ Вторая группа - ФГАОУ ВО } \\
\hline & $\begin{array}{l}\text { СПб } \\
\text { ГУ }\end{array}$ & $\begin{array}{l}\text { СПб } \\
\text { ГЭУ }\end{array}$ & $\begin{array}{c}\text { СПб ГТИ } \\
\text { (ТУ) }\end{array}$ & $\begin{array}{c}\text { СПб } \\
\text { Горный } \\
\text { универ- } \\
\text { ситет }\end{array}$ & $\begin{array}{l}\text { СПб } \\
\text { ПУ }\end{array}$ & $\begin{array}{c}\text { Универ- } \\
\text { ситет } \\
\text { ИТМО }\end{array}$ & $\begin{array}{c}\text { СПб } \\
\text { ЭТУ } \\
\text { «ЛЭТИ» }\end{array}$ \\
\hline Число студентов всего, чел. & 18832 & 13074 & 7034 & 7311 & 29095 & 12153 & 8534 \\
\hline $\begin{array}{l}\text { в т.ч. } \\
\text { - очной формы обучения }\end{array}$ & 18205 & 9884 & 3725 & 7285 & 21461 & 10971 & 7561 \\
\hline $\begin{array}{l}\text { Число иностранных студен- } \\
\text { тов, чел. }\end{array}$ & 1939 & 947 & 358 & 468 & 3706 & 1663 & 1445 \\
\hline $\begin{array}{l}\text { Доля иностранных студентов } \\
\text { в общей численности,\% }\end{array}$ & 10,3 & 8,22 & 5,1 & 6,4 & 12,74 & 13,68 & 16,93 \\
\hline Всего работников ВУЗа, чел. & 9856 & 2057 & 958 & 1873 & 4723 & 3001 & 2042 \\
\hline $\begin{array}{l}\text { в т.ч. } \\
\text { - НПР; }\end{array}$ & 3831 & 865 & 408 & 610 & 1658 & 803 & 803 \\
\hline $\begin{array}{l}\text { - НПР, имеющие ученую } \\
\text { степень,\% }\end{array}$ & 77,32 & 82,54 & 80,64 & 92,13 & 74,73 & 71,23 & 71,86 \\
\hline Научных работников, чел., & 411 & 1 & 50 & 78 & 500 & 97 & 80 \\
\hline - имеющие ученую степень,\% & 63,2 & 100 & 62,0 & 62,82 & 73,28 & 80,41 & 62,02 \\
\hline
\end{tabular}

Источник. Составлено авторами на основе данных: http://indicators.miccedu.ru/monitoring/ 
технических науках - СПб ПУ (14,8\%), Университет ИТМО $(10,6 \%)$ и СПб ЭТУ «ЛЭТИ» $(8 \%)$;

- в науках об обществе - СПб ГЭУ $(13,8 \%)$, СПбГУ (12,7\%) и СПб ПУ (11,0\%);

- в гуманитарных науках - СПбГУ $(23,4 \%)$ и СПб ПУ (5,0\%).

Остальные университеты по основным направлениям наук обладают незначительным удельным весом от $0,3 \%$ до $1,7 \%$. Таким образом, в целом, все вышеуказанные анализируемые университеты г. Санкт-Петербург, независимо от организационно-правовой формы хозяйствования, можно отнести к многопрофильным университетам.

Федеральная целевая программа развития образования на 2016-2020 годы России предусматривает создание условий для эффективного развития российского образования, направленного на обеспечения его доступности и повышения качества, отвечающего требованиям современного инновационного социально-экономического ориентированного развития реальной экономики страны [8].

Согласно индикаторам данной Программы, в результате выполнения ее второго этапа (2018-2020 гг.) будет сформирована сеть образовательных организаций высшего образования, включая многопрофильные опорные университеты, ориентирующиеся на ключевые отрасли региональных экономик, реализующие, в том числе программы магистратуры и аспирантуры, ведущие активную научно-исследовательскую и инновационную деятельность.

Изучив показатели мониторинга эффективности семи многопрофильных университетов, получены среднегодовые фактические значения мониторинга по каждому ВУЗу (2016-2018 гг.). Рассмотрим некоторые из них, усредненные показатели которых представлены в таблице ниже (табл. 4):

1. Показатель «Образовательная деятельность». Наивысшее фактическое значение мониторинга среднего балла ЕГЭ отмечено в Университете ИТМО в 2018 году (86,98 баллов), СПбГУ в 2017 году (86,01 балла). В целом, более высокие значения данного показателя достигли ВУЗы второй группы - от 74,85 до 86,98 балла, тогда как в рамках первой группы данный показатель колебался от 67,52 до 86,01 балла за исследуемый период. Темпы роста (отношение показателей 2018 года к 2016 году, выраженное в процентах) фактического значения мониторинга данного показателя в ВУЗах второй группы составили от 103,73\% до 114,93\%, тогда как в ВУЗах первой группы данный показатель колебался в пределах от 95,27\% до 102,23\%.

2. Показатель «Научно-исследовательская деятельность». Среди семи исследуемых университетов преодолели пороговое значение шесть вузов, кроме СПб ГЭУ. Наивысших показателей фактического значения мониторинга достигли Университет ИТМО (2 787,11 тыс.руб. в 2018 году) и СПб Горный университет (1774,75 тыс.руб. в 2017 году). По данному показателю в целом на-

Таблица 4. Показатели мониторинга эффективности многопрофильных университетов г. Санкт-Петербург

\begin{tabular}{|c|c|c|c|c|c|c|c|c|}
\hline \multirow{3}{*}{$\begin{array}{c}\text { Наименование } \\
\text { показателя } \\
\text { мониторинга }\end{array}$} & \multirow{3}{*}{$\begin{array}{c}\text { Поро- } \\
\text { говое } \\
\text { значение }\end{array}$} & \multicolumn{4}{|c|}{ Первая группа - ФГБоу во } & \multicolumn{3}{|c|}{ Вторая группа - ФГАОУ ВО } \\
\hline & & \multicolumn{7}{|c|}{ фактическое значение мониторинга } \\
\hline & & $\begin{array}{l}\text { СПб } \\
\text { ГУ }\end{array}$ & $\begin{array}{l}\text { СПб } \\
\text { ГЭУ }\end{array}$ & $\begin{array}{c}\text { СПбГТИ } \\
\text { (ТУ) }\end{array}$ & $\begin{array}{c}\text { СПб } \\
\text { Горный } \\
\text { универ- } \\
\text { ситет }\end{array}$ & $\begin{array}{l}\text { СПб } \\
\text { ПУ }\end{array}$ & $\begin{array}{c}\text { Универ- } \\
\text { ситет } \\
\text { ИТМО }\end{array}$ & $\begin{array}{c}\text { СПб } \\
\text { ЭТУ } \\
\text { «ЛЭТИ» }\end{array}$ \\
\hline $\begin{array}{l}\text { Образовательная } \\
\text { деятельность }\end{array}$ & 66,38 & 85,42 & 72,65 & 66,68 & 73,49 & 73,71 & 82,25 & 74,72 \\
\hline $\begin{array}{l}\text { Научно-исследователь- } \\
\text { ская деятельность }\end{array}$ & 122,4 & 425,2 & 41,1 & 298,7 & 1597,0 & 583,8 & 2502,8 & 675,3 \\
\hline $\begin{array}{l}\text { Международная } \\
\text { деятельность }\end{array}$ & 4,92 & 7,01 & 7,43 & 3,33 & 6,66 & 12,28 & 13,05 & 16,03 \\
\hline $\begin{array}{l}\text { Финансово-экономи- } \\
\text { ческая деятельность }\end{array}$ & 1839,9 & 2641,8 & 3028,1 & 2481,2 & 5410,8 & 3179,1 & 6330,9 & 2401,9 \\
\hline Заработная плата НПР & 150,00 & 158,49 & 165,67 & 162,42 & 202,07 & 168,88 & 233,19 & 162,47 \\
\hline Трудоустройство & 70,0 & 71,7 & 76,7 & 78,3 & 83,3 & 76,7 & 75,6 & 71,7 \\
\hline $\begin{array}{l}\text { Дополнительный } \\
\text { показатель }\end{array}$ & 4,52 & 16,02 & 4,50 & 4,10 & 8,24 & 4,99 & 4,74 & 6,52 \\
\hline
\end{tabular}

Источник. Составлено авторами на основе данных: http://indicators.miccedu.ru/monitoring/ 
блюдается положительная тенденция темпов роста - от $107,96 \%$ до $152,77 \%$.

3. Показатель «Международная деятельность». Наибольшие фактические значения сложились в университетах второй группы, которые значительно превысили пороговое значение (4,92\%) от $12,29 \%$ до $15,97 \%$ в 2017 году, а 2018 году достигли значений в пределах от 13,75\% до $18,12 \%$. Тогда как, в рамках первой группы данный показатель сформировался в пределах от $4,81 \%$ до 10,53\%. Не следует забывать о целевых индикаторах программ развития образовательной сферы, среди которых - к 2020 году пороговое значение данного показателя мониторинга эффективности ВУЗов должно составлять не менее $15,0 \%$. Темпы роста фактического значения показателя среди университетов первой группы за анализируемый период времени сложились в пределах от $110,63 \%$ (в СПб ГЭУ) до $150,21 \%$ в (СПб ГУ).

4. Показатель «Финансово-экономическая деятельность». Все анализируемые ВУЗы г. Санкт-Петербург преодолели пороговые значения данного показателя. Особенно высокого уровня доходов по всем видам деятельности, в расчете на одного НПР достигли все университеты в 2018 году в целом. Однако наивысшее фактическое значение показателя за исследуемый период достигли в 2018 году Университет ИТМО - 6469,7 тыс.руб. (вторая группа) и в 2016 году СПб Горный университет - 6297,97 тыс.руб. Средние темпы роста значения индикатора мо- ниторинга в 2016-2018 гг. составили от 104,91\% до $158,87 \%$.

По остальным показателям «Заработная плата ППС» И «Трудоустройство» все университеты преодолели пороговое значение. По показателю «Дополнительный показатель» не преодолели пороговое значение три университета - СПб ГТИ (ТУ), Университет ИТМО и СПб ПУ.

Пороговые значения мониторинга эффективности вузов, применяемые в 2016-2018 гг. в среднем по РФ для многопрофильных университетов, которые вошли в рейтинг 100 лучших вузов России оказались легко выполнимыми, так как фактические значения мониторинга эффективности значительно выше пороговых значений.

Однако, как отмечалось ранее, данный набор критериев, по мнению авторов и других исследователей, интересующихся развитием системы образования, его интернационализации и проблем повышения его конкурентоспособности, так как не учитывают специфику, региональные и отраслевые особенности [1, 2, 4, 5 и др.].

На основе проведенного анализа и оценки показателей мониторинга эффективности лучших многопрофильных университетов г. Санкт-Петербург авторами сделана попытка на уровне субъекта РФ определить для данных университетов реальное пороговое значение мониторинга эффективности образовательной организации высшего образования, нивелирующих или частично исключающих вышеупомянутые недостатки (табл.5).

Таблица 5. Варианты порогового значения показателей мониторинга эффективности многопрофильных университетов (новые)

\begin{tabular}{|c|c|c|c|c|c|c|c|}
\hline \multirow{2}{*}{$\begin{array}{c}\text { Показатели } \\
\text { мониторинга }\end{array}$} & \multirow{2}{*}{$\begin{array}{c}\text { Пороговое } \\
\text { значение }\end{array}$} & \multicolumn{3}{|c|}{ Фактическое значение } & \multicolumn{3}{|c|}{$\begin{array}{c}\text { Варианты порогового значения } \\
\text { (новые) }\end{array}$} \\
\hline & & $\begin{array}{l}\text { Мини- } \\
\text { мум }\end{array}$ & $\begin{array}{l}\text { Макси- } \\
\text { мум }\end{array}$ & Среднее & 1 & 2 & 3 \\
\hline $\begin{array}{l}\text { Образовательная } \\
\text { деятельность }\end{array}$ & 66,38 & 67,52 & 86,98 & 77,25 & 85,0 & 80,0 & 75,0 \\
\hline $\begin{array}{l}\text { Научно-исследователь- } \\
\text { ская деятельность }\end{array}$ & 122,41 & 339,81 & 2787,11 & 1563,46 & 2100,0 & 1600,0 & 1100,0 \\
\hline $\begin{array}{l}\text { Международная } \\
\text { деятельность }\end{array}$ & 4,92 & 4,81 & 18,12 & 11,47 & 20,0 & 17,0 & 15,0 \\
\hline $\begin{array}{l}\text { Финансово-экономиче- } \\
\text { ская деятельность }\end{array}$ & 1839,87 & 2665,34 & 6469,70 & 4567,52 & 6500,0 & 5500,0 & 4500,0 \\
\hline Заработная плата ППС & 150,0 & 160,72 & 245,78 & 203,25 & 200,0 & 190,0 & 170,0 \\
\hline Трудоустройство & 70,0 & 70,0 & 85,0 & 77,50 & 80,0 & 75,0 & 70,0 \\
\hline $\begin{array}{l}\text { Дополнительный } \\
\text { показатель }\end{array}$ & 4,52 & 3,85 & 16,13 & 10,0 & 17,0 & 15,0 & 10,0 \\
\hline
\end{tabular}

Источник. Составлено авторами на основе данных: http://indicators.miccedu.ru/monitoring/, https://raexpert.ru/ и результатов собственных исследований. 
Согласно рейтингу 100 лучших ВУЗов России агентства Эксперт РА в 2015-2018 гг. и оценки показательной многопрофильные университеты, которые «вошли в первую десятку» ВУЗов, рекомендуем устанавливать новое пороговое значение в пределах варианта 1. Университеты, которые заняли с 11-го по 20-е места включительно - рекомендуется новое пороговое значение в пределах варианта 2. ВУЗы, которые заняли с 21-го места и далее - рекомендуемое новое пороговое значение в пределах варианта 3 .

В современных условиях необходимо постоянно совершенствовать систему показателей эффективности мониторинга ВУЗов и его критериев, более объективно и всесторонне отражающей результативность деятельности многопрофильных университетов, ориентирующиеся на ключевые отрасли региональной экономики.

Для многопрофильных университетов, считаем необходимо ввести дополнительный показатель по научно-исследовательской деятельности - показатель РИНЦ,- и установить его на уровне не менее 2-5 научных статей в год на одного штатного НПР, опубликованные в журналах, сборниках и других изданиях, включенных национальную библиографическую базу данных научного цитирования.

Для подтверждения статуса многопрофильного университета считаем, что кроме имеющихся профильных направлений науки, необходимо вести деятельность по следующим направлениям - науки об обществе и гуманитарные науки,- с целью повышения трансдисциплинарности образовательного процесса и научных исследований. В данном случае, положительным опытом обладает СПб ПУ, потому считаем, что оптимальная доля обучающихся студентов должна составлять не менее 9-10\%\% в рамках наук об обществе и не менее 5-7\%\% в рамках гуманитарных наук.

Критерии эффективности мониторинга образовательных организаций высшего образования должны быть связаны с показателями государственной аккредитации ВУЗов. Набор показателей при построении рейтингов и процедуре мониторинга во многом совпадают, поэтому для унификации работы и снижения трудоемкости сбора информации могут быть сформированы единый перечень. С другой стороны - анализ и трактовка показателей для всевозможных целей (мониторинга и рейтинга) могут различаться.

\section{Библиографический список}

1. Винокуров М.А. Мониторинг эффективности российских вузов: совершенствование методологии // Известия БГУ. 2013. № 6.- URL: https://cyberleninka.ru/article/n/monitoring-effektivnosti-rossiyskih-vuzovsovershenstvovanie-metodologii (дата обращения: 05.02.2019).

2. Ильинский И.М. Об эффективности мониторинга вузов // Знание. Понимание. Умение. 2013. № 2.- URL: https://cyberleninka.ru/article/n/ob-effektivnosti-monitoringa-vuzov (дата обращения: 25.01.2019).

3. Методика расчета показателей мониторинга эффективности образовательных организаций высшего образования 2017 года (на основе данных формы № 1-Моноторинг за 2016): утвержденная Министерством образования и науки РФ 14 марта 2017 г. № ЛО-27/05вн // Официальный сайт компании «Гарант». Режим доступа: http://www.garant.ru/products/ipo/prime/doc/71535890/ (дата обращения: 24.01.2019).

4. Мотова Г.Н. Технология государственной аккредитации / Г.Н. Мотова, В.Г. Наводнов // Аккредитация. ru: Йошкар-Ола: Учебно-консультационный центр, 2016.- Ч.4. - 80 с.

5. Прохоров С.Г., Свирина А.А., Чехонадских А.И. Мониторинг эффективности: инструмент сокращения или поиск точек роста? // Высшее образование в России. 2016. № 1.- URL: https://cyberleninka.ru/article/n/ monitoring-effektivnosti-instrument-sokrascheniya-ili-poisk-tochek-rosta (дата обращения: 25.01.2019).

6. Об образовании в Российской Федерации от 29.12.2012 № 273-Ф3 (действующая редакция) // Официальный сайт Закона об образовании в РФ. Режим доступа: http://zakon-ob-obrazovanii.ru/ (дата обращения: 04.02.2019).

7. Федеральной целевой программе развития образования на 2016-2020 годы: Постановление Правительства РФ от 23.05.2015 № 497 // Официальный сайт компании «Гарант». Режим доступа: http://base.garant. $\mathrm{ru} / 71044750$ / (дата обращения: 04.02.2019).

8. Янова E. А. Показатели рейтинга RAEX университетов Северо-Западного федерального округа России как подход к оценке качества образования./Новые технологии оценки качества образования: сборник материалов Х11 Форума экспертов в сфере профессионального образования (Москва, 18 ноября, 2017 г.) - 2017.C. $80-85$. 
9. Янова Е.А., Янова В.В. Методика проведения процедуры государственной аккредитации при проверке образовательных программ по направлению экономика // Новые технологии оценки качества образования: сборник материалов X1 Форума экспертов в сфере профессионального образования / под общей редакцией д.п.н. Г.Н. Мотовой.- М.: Гильдия экспертов в сфере профессионального образования, 2016. - 331с.

10. Янова Е.А., Уфимцева А.Ю. и др. Структурные изменения в экономике России как фактор экономического роста // Фундаментальные и прикладные исследования: проблемы и результаты - 2016. - № 24. С. $203-207$.

11. Blase J. Some Negative Effects of Principal's Control Oriented and Prospective Political behavior // American Education Research Journal. 1990. Vol. 4. P. 727-753. 